\title{
ADVANCED LIGHTNING CURRENT GENERATORS
}

\author{
Quyen Huy Anh ${ }^{(1)}$, Nguyen Manh Hung ${ }^{(1)}$, Ta Van Minh ${ }^{(2)}$ \\ (1) University of Technical Education - HoChiMinh City \\ (2) Lilama College \\ (Manuscript Received on January $11^{\text {st }} 2011$, Manuscript Revised January $14^{\text {th }}$ 2012)
}

\begin{abstract}
Lightning current impulse circuit researches have used various schematics for diverse impulses, which makes several problems for lightning current impulse generator fabrication with a suitable cost. In addition, errors of several lightning current impulse math models have not met the standards. This work presents solutions to determination of parameters for a specific lightning current impulse circuit and a lightning current impulse math model which is in Matlab environment with high accuracy.
\end{abstract}

Keywords: Lightning current impluse generator

\section{INTRODUCTION}

Researching on effects of lightning current impulses is important to selection of lightning-strokeprotective devices and overvoltage calculation on grid. Lightning current circuit researches have applied various schematics for diverse impulses, which makes several issues for lightning current impulse generator fabrication with a reasonable price. Furthermore, some of proposed lightning current impulse generator physical models have the front and half-value errors greater than the standard ones [2]. Therefore, it is necessary to research and propose a lightning current impulse generator model generating various wave shapes with high accuracy and suitable price.

This work presents the approximate method of quickly calculating basic parameters of lightning current impulse generator and the error-evaluating method of correcting the front error and the halfvalue error as the standards.

In addition, lightning current impulse math models for wave shapes $8 / 20 \mu$ s and $4 / 10 \mu$ s are proposed in Matlab environment.

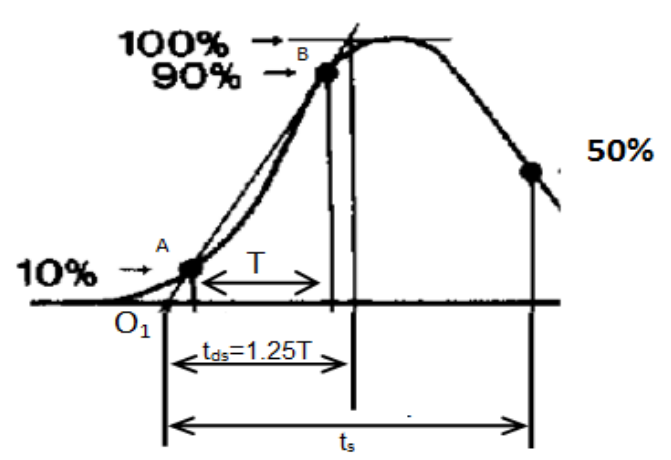

Figure 1. Standard wave shape

\section{STANDARD LIGHTNING CURRENT IMPULSE WAVE SHAPES}

Typical lightning current impulse wave shapes have been defined in the standards as Figure 1. Front error and half-value error are required less than $10 \%$. [3].

Table 1 presents several universal lighting current impulses with front time $t_{d s}$ and time to half value $t_{s}$. 
Table 1. Standard lighting current impulses

\begin{tabular}{|c|c|c|c|c|c|}
\hline $\begin{array}{c}\text { Wave shape } \\
(\mu \mathrm{s})\end{array}$ & $\mathrm{t}_{\mathrm{ds}}(\mu \mathrm{s})$ & $\mathrm{t}_{\mathrm{s}}(\mu \mathrm{s})$ & $\begin{array}{c}\text { Wave shape } \\
(\mu \mathrm{s})\end{array}$ & $\mathrm{t}_{\mathrm{ds}}(\mu \mathrm{s})$ & $\mathrm{t}_{\mathrm{s}}(\mu \mathrm{s})$ \\
\hline $10 / 700$ & $10 \pm 10 \%$ & $700 \pm 10 \%$ & $1 / 200$ & $1 \pm 10 \%$ & $200 \pm 10 \%$ \\
\hline $1.2 / 50$ & $1.2 \pm 10 \%$ & $50 \pm 10 \%$ & $10 / 350$ & $10 \pm 10 \%$ & $350 \pm 10 \%$ \\
\hline $2 / 25$ & $2 \pm 10 \%$ & $25 \pm 10 \%$ & $1 / 5$ & $1 \pm 10 \%$ & $5 \pm 10 \%$ \\
\hline $2 / 50$ & $2 \pm 10 \%$ & $50 \pm 10 \%$ & $4 / 10$ & $4 \pm 10 \%$ & $10 \pm 10 \%$ \\
\hline $0.25 / 100$ & $0.25 \pm 10 \%$ & $100 \pm 10 \%$ & $8 / 20$ & $8 \pm 10 \%$ & $20 \pm 10 \%$ \\
\hline
\end{tabular}

\section{LIGHTNING CURRENT CIRCUIT MODEL}

\subsection{Lightning current circuit schematic}

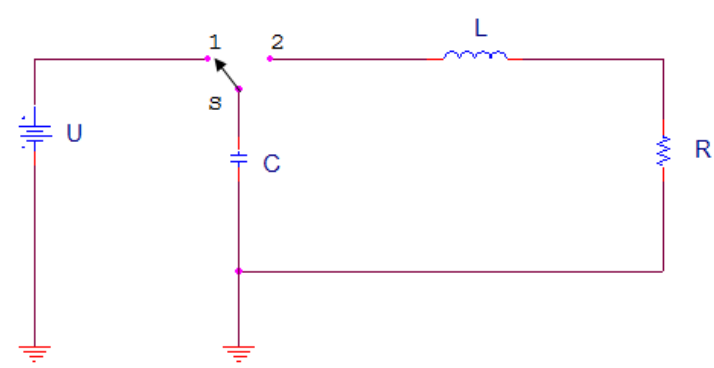

Figure 2. Lightning current circuit schematic
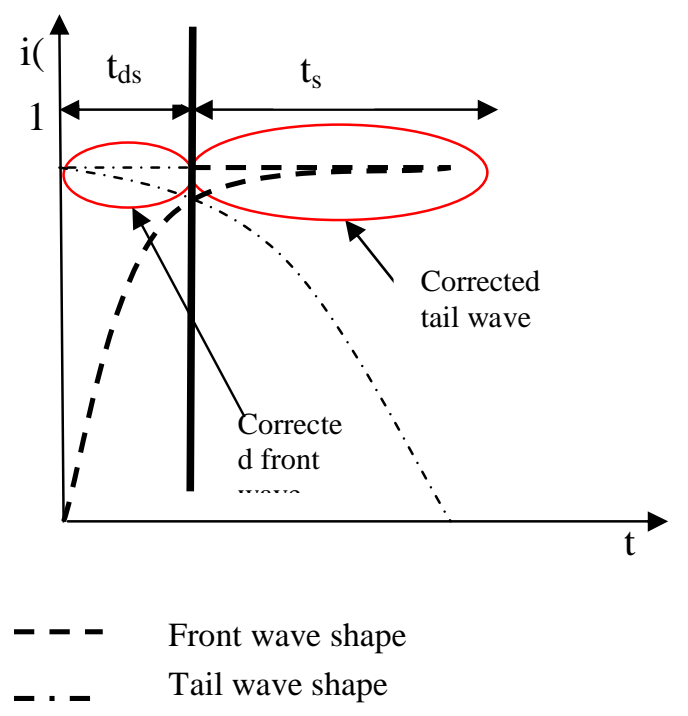

Figure 3. Front and tail wave shapes

By solving integral- differential equation and using Laplace transformation, the time dependent current passing through lightning current circuit can be obtained as equation (1):

$$
i(t)=\frac{U}{R A}\left(e^{-\frac{t}{t_{2}}}-e^{-\frac{t}{t_{2}}}\right)
$$

Where: $\mathrm{A}=\sqrt{1-4 Q^{2}}, \mathrm{Q}=\omega_{\mathrm{ch}} / 2 \alpha$

$$
\alpha=\mathrm{R} / 2 \mathrm{~L}, \omega_{\mathrm{ch}}=1 / \sqrt{L C}
$$

$$
\left\{\begin{array}{l}
\frac{1}{t_{1}}=\frac{R}{2 L}+\sqrt{\frac{R^{2}}{4 L^{2}}-\frac{1}{L C}} \\
\frac{1}{t_{2}}=\frac{R}{2 L}-\sqrt{\frac{R^{2}}{4 L^{2}}-\frac{1}{L C}}
\end{array}\right.
$$

Assigning $p=t_{2} / t_{1}$ and $I_{m}=U / R A$, equation (1) can be rewriten as equation (2):

$$
i(t)=I_{m} \cdot \theta^{\frac{-t}{t_{2}}}\left(1-e^{(p-1) \frac{-t}{t_{2}}}\right)
$$

To achieve a standard lightning current, parameters $\mathrm{p}$ and $\mathrm{t}_{2}$ must be selected correctly. Then based on equations (3) and (4), the resistance, inductance and capacitance of the circuit can be estimated.

$$
\left\{\begin{array}{l}
\mathrm{L}=\frac{t_{2}^{2}}{p C} \\
\mathrm{R}=\frac{(3+1) L}{t_{2}}=\frac{(p+1) t_{2}}{p^{2} C}
\end{array}\right.
$$

3.2 Estimate parameters for lightning current impluse generator

\subsubsection{Approximate method}


The equation (2) shows that functions $e^{-\frac{t}{t_{2}}}$ and $\left[1-e^{-\frac{(p-1) t}{t_{2}}}\right]$ generate front and tail wave shapes, respectively.

When applied with the approximate method, the wave shapes can be presented in Figure 3.

In the period of tail time, it is assumed that $\left[1-e^{-\frac{(p-1)}{t_{z}}}\right]=1$. Equation (2) can be rewritten as below:

$$
i(t)=I_{m} e^{\left(\frac{-t}{t_{2}}\right)}
$$

Therefore, $i(t)=0,5 \cdot I_{m}$ if $t=t_{s}-t_{\text {ds }}$.

$$
\begin{aligned}
\text { So: } I_{m} e^{\frac{-\left(t_{5}-t_{d s}\right)}{t_{2}}}=0.5 I_{m} \\
\text { Hence: } t_{\mathbf{z}}=\frac{t_{s}-t_{d s}}{\ln (2)}
\end{aligned}
$$

Similarly, in the period of front time, it is assumed that $e^{-\frac{t}{t_{2}}}=1=1$, the time dependent current can be present as below:

\begin{tabular}{|c|c|c|c|c|c|c|c|c|c|c|c|}
\hline \multicolumn{2}{|c|}{ Standard $(\mu s)$} & \multirow[b]{2}{*}{$\mathrm{t}_{\mathrm{s}} / \mathrm{t}_{\mathrm{ds}}$} & \multirow[b]{2}{*}{$\mathrm{t}_{2}$} & \multirow[b]{2}{*}{$\mathrm{p}$} & \multirow[b]{2}{*}{$\mathrm{R}$} & \multirow[b]{2}{*}{$\mathrm{L}$} & \multirow[b]{2}{*}{$\mathrm{C}$} & \multicolumn{2}{|c|}{ Calculated $(\mu \mathrm{s})$} & \multicolumn{2}{|c|}{ Error $(\%)$} \\
\hline $\mathrm{t}_{\mathrm{ds}}$ & $t_{s}$ & & & & & & & $t_{d s}$ & $\mathrm{t}_{\mathrm{s}}$ & $\begin{array}{l}\text { Front } \\
\text { wave }\end{array}$ & $\begin{array}{r}\text { Tail } \\
\text { wave }\end{array}$ \\
\hline 10 & 700 & 70 & 0.000995 & 274.406 & 9.9909 & 3.61E-05 & 0.0001 & $9.38 \mathrm{E}-06$ & 0.00071 & 6.25 & 2.11 \\
\hline 1.2 & 50 & 41.67 & $7.04 \mathrm{E}-05$ & 162.1379 & 0.7084 & $3.06 \mathrm{E}-07$ & 0.0001 & $1.13 \mathrm{E}-06$ & $5.17 \mathrm{E}-05$ & 6.25 & 3.44 \\
\hline 2 & 25 & 12.5 & $3.32 \mathrm{E}-05$ & 46.56767 & 0.3389 & $2.36 \mathrm{E}-07$ & 0.0001 & $1.63 \mathrm{E}-06$ & 2.67E-05 & 18.75 & 6.8 \\
\hline 2 & 50 & 25 & 6.92E-05 & 96.09775 & 0.6997 & 4.99E-07 & 0.0001 & $1.75 \mathrm{E}-06$ & $5.22 \mathrm{E}-05$ & 12.5 & 4.4 \\
\hline 0.3 & 100 & 400 & 0.000144 & 1582 & 1.44 & $1.31 \mathrm{E}-07$ & 0.0001 & $2.50 \mathrm{E}-07$ & 0.0001 & 0 & 0.63 \\
\hline 1 & 200 & 200 & 0.000287 & 789.5188 & 2.8746 & $1.04 \mathrm{E}-06$ & 0.0001 & $1.00 \mathrm{E}-06$ & 0.0002 & 0 & 0.01 \\
\hline 10 & 350 & 35 & 0.000491 & 135.7218 & 4.9413 & $1.77 \mathrm{E}-05$ & 0.0001 & $9.00 \mathrm{E}-06$ & 0.00036 & 10 & 3.49 \\
\hline 1 & 5 & 5 & 5.77E-06 & 16.84963 & 0.0611 & $1.98 \mathrm{E}-08$ & 0.0001 & $7.50 \mathrm{E}-07$ & $5.60 \mathrm{E}-06$ & 25 & 12 \\
\hline 4 & 10 & 2.5 & $8.66 \mathrm{E}-06$ & 6.943609 & 0.099 & $1.08 \mathrm{E}-07$ & 0.0001 & $1.88 \mathrm{E}-06$ & $1.06 \mathrm{E}-05$ & 53.13 & 6 \\
\hline 8 & 20 & 2.5 & $1.73 \mathrm{E}-05$ & 6.943609 & 0.1981 & $4.32 \mathrm{E}-07$ & 0.0001 & $3.75 \mathrm{E}-06$ & $2.10 \mathrm{E}-05$ & 53.13 & 5 \\
\hline
\end{tabular}

$$
i(t)=I_{m}\left[1-e^{-(p-1) \frac{t}{t_{2}}}\right]
$$

Table 2. Parameters R, L and C calculated by the approximate method

The amplitude of current reaches $0.1 \mathrm{I}_{\mathrm{m}}$ at $\mathrm{t}_{10 \%}$ and $0.9 \mathrm{I}_{\mathrm{m}}$ at $\mathrm{t}_{90 \%}$. Therefore:

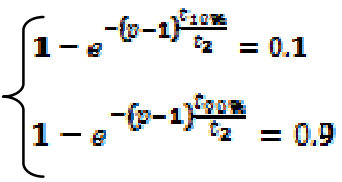

Solving the system equations above, the parameter $\mathrm{p}$ can be estimated as equation (6):

$$
p=\frac{\ln (0.9)-\ln (0.1)}{0.8 t_{d s}}\left(t_{2}\right)+1
$$

Based on equation 5 and 6 , the result of estimating the parameters is shown in Table 2. The result shows that front and half-value errors of wave shapes having great fraction $\mathrm{t}_{\mathrm{s}} / \mathrm{t}_{\mathrm{ds}}(10 / 700 ; 1.2 / 50$; $0.3 / 100 ; 1 / 200 ; 10 / 350 \mu \mathrm{s})$ meet the standards. On the other hand, wave shapes having low fraction $t_{\mathrm{s}} / \mathrm{t}_{\mathrm{ds}}$ $(1 / 5 ; 4 / 10 ; 8 / 20 ; 10 / 350 ; 2 / 25 ; 2 / 50 \mu s)$ do not satisfy the requirements. 


\subsubsection{Error-evaluating method}

To estimate parameters of lightning current impulses generators with low fraction $\mathrm{t}_{\mathrm{s}} / \mathrm{t}_{\mathrm{ds}}$, the errorevaluating method is a better solution to reduce the front error and half-value error. The method is based on error deflection and relative error evaluation for current wave forms.

It is assigned that $d_{1}, d_{2}$ and $d$ are front error deflection, half-value error deflection and accumulated error deflection, respectively.

Accumulated error deflection is estimated as equations below:

$$
\begin{aligned}
& \mathrm{d}_{=}=\mathrm{d}_{1}+\mathrm{d}_{2} \\
& \begin{cases}\mathrm{~d}_{1}=0 & \text { if } 0.9 \mathrm{t}_{\mathrm{ds}}<\mathrm{t}_{\mathrm{a}}<1.1 \mathrm{t}_{\mathrm{ds}} \\
\mathrm{d}_{1}=0.9 \mathrm{t}_{\mathrm{ds}} \mathrm{t}_{\mathrm{a}} & \text { if } \mathrm{t}_{\mathrm{a}}<0.9 \mathrm{t}_{\mathrm{ds}} \\
\mathrm{d}_{1}=\mathrm{t}_{\mathrm{a}}-1.1 \mathrm{t}_{\mathrm{ds}} & \text { if } \mathrm{t}_{\mathrm{a}}>1.1 \mathrm{t}_{\mathrm{ds}}\end{cases} \\
& \begin{cases}\mathrm{d}_{2}=0 & \text { if } 0.9 \mathrm{t}_{\mathrm{s}}<\mathrm{t}_{\mathrm{b}}<1.1 \mathrm{t}_{\mathrm{s}} \\
\mathrm{d}_{2}=\mathrm{t}_{\mathrm{b}}-1.1 \mathrm{t}_{\mathrm{s}} & \text { if } \mathrm{t}_{\mathrm{b}}>1.1 \mathrm{t}_{\mathrm{s}} \\
\mathrm{d}_{2}=0.9 \mathrm{t}_{\mathrm{s}} \mathrm{t}_{\mathrm{b}} & \text { if } \mathrm{t}_{\mathrm{b}}<0.9 \mathrm{t}_{\mathrm{s}} \\
\text { Where: } \mathrm{t}_{\mathrm{a}} & \text { is } \quad \text { the estimated front time, }\end{cases}
\end{aligned}
$$
$\mathrm{t}_{\mathrm{a}}=1.25 *\left(\mathrm{t}_{90 \%}-\mathrm{t}_{10 \%}\right) ; \mathrm{t}_{\mathrm{b}}$ is the estimated half value time, $\mathrm{t}_{\mathrm{b}}=\mathrm{t}_{50 \%}-\mathrm{t}_{10 \%}+0.1 \mathrm{t}_{\mathrm{a}}$.

It is assigned $e_{1}, e_{2}$ and $e$ are front error, halfvalue error and accumulated error, respectively. Then:

$$
\mathrm{e}=\mathrm{e}_{1}+\mathrm{e}_{2} \text {. }
$$

Where: $\quad \mathrm{e}_{1}=\left|\mathrm{t}_{\mathrm{a}}-\mathrm{t}_{\mathrm{ds}}\right| / \mathrm{t}_{\mathrm{ds}}$;

$\mathrm{e}_{2}=\left|\mathrm{t}_{\mathrm{b}}-\mathrm{t}_{\mathrm{s}}\right| / \mathrm{t}_{\mathrm{s}}$.

Parameters $\mathrm{p}$ and $\mathrm{t}_{2}$ must reach the conditions (7) and (8):

$$
\begin{aligned}
& 1<p<\frac{\ln (0.9)-\ln (0.1)}{0.8 t_{d s}} \frac{t_{s}-t_{d s}}{\ln (2)} \\
& \frac{0.8 . t_{d s} \cdot(p-1)}{\ln (p)}<t_{2}<\frac{1.1 t_{g}-0.9 t_{s}}{\ln (2)}
\end{aligned}
$$

Among values $\left(\mathrm{p}, \mathrm{t}_{2}\right)$ passing conditions (7) and (8), the values reaching the condition " $d=0$ " mean the errors pass the standard. If " $\mathrm{d}=0$ "- reaching values are available, the value with the minimum accumulated error is the best option. In the case that no value $\left(\mathrm{p}, \mathrm{t}_{2}\right)$ supports condition " $\mathrm{d}=0$ ", the value having the minimum accumulated deflection will be chose as the best option.

Based on the error-evaluating method, round values $\mathrm{R}, \mathrm{L}$ and $\mathrm{C}$ are presented in Table 3. Through this result, wave shapes $8 / 20 \mu$ s and $4 / 10 \mu$ s are only two conditions not achieving the requirements, and the errors are lower than proposed models [2].

\section{HEIDLER MATH MODEL}

\subsection{Heidler equation}

Heidler equation is one of equations that used to express lighting current impulses [4]:

$$
i(t)=\frac{I_{m}}{\mu} \frac{\left(t / \tau_{1}\right)^{10}}{\left(t / \tau_{1}\right)^{10}+1} e^{-\frac{t}{\tau_{2}}}
$$

Where: $I_{m}$ is peak current $(k A) ; \tau_{1}$ is increasing current time coefficient $(\mu \mathrm{s}) ; \tau_{2}$ is decreasing current time coefficient $(\mu s) ; \mu$ is peak-current-adjusting coefficient.

Applied with the approximate method, in the period of front time, it is assumed that $e^{-\frac{t}{\tau_{2}}}=\mathbf{1}$. Therefore, equation (9) can be rewritten:

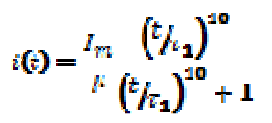

The amplitude of current reaches $0.1 \mathrm{I}_{\mathrm{m}}$ at $\mathrm{t}_{10 \%}$ and $0.9 \mathrm{I}_{\mathrm{m}}$ at $\mathrm{t}_{90 \%}$. Therefore.

Hence:

$$
\begin{aligned}
& \frac{\left(t_{10 \%} / \tau_{1}\right)^{10}}{\left(t_{10 \times} / \tau_{1}\right)^{10}+1}=0.1 \\
& \frac{\left(t_{90} \times / \tau_{1}\right)^{10}}{\left(t_{90} \times / \tau_{1}\right)^{10}+1}=0.9
\end{aligned}
$$

\section{Trang 88}


Solving the systems of equation (10), parameter

$\tau_{1}$ can be estimated base on equation (11):

$$
\tau_{1}=\frac{0.8 t_{d s}}{\sqrt[90]{9}-\sqrt[10]{\frac{1}{5}}}
$$

Similarly, in the period of tail time, assume that $\frac{\left(t / r_{1}\right)^{10}}{\left(t / r_{1}\right)^{10}+1}-1$

as below:

$$
i(t)=\frac{I_{\mathrm{m}}}{\mu} e^{-\frac{t}{\tau_{\mathbf{z}}}}
$$

At $\mathrm{t}=\mathrm{t}_{\mathrm{s}}-\mathrm{t}_{\mathrm{ds}}$ the current value reaches a half of the peak value.
Hence: $e^{-\frac{\tau_{3}-t_{d z}}{\tau_{2}}}=0.5$

$$
\tau_{\mathbf{z}}=\frac{t_{s}-t_{d s}}{\ln (2)}
$$

Errors of the lightning currents based on equation (10) and (11) are shows in Table 4. Through this table, even if errors of wave forms 8-20, 4-10 $\mu$ s have been reduced in comparison with equation (1), they still do not pass for the requirements when the approximate method is applied.

Table 3. Parameters R, L and $\mathrm{C}$ estimated by the error-evaluating method

\begin{tabular}{|l|l|l|l|l|l|l|}
\hline \multicolumn{1}{|c|}{$\mathrm{t}_{\mathrm{ds}}(\mu \mathrm{s})$} & $\mathrm{t}_{\mathrm{s}}(\mu \mathrm{s})$ & $\mathrm{R}(\Omega)$ & $\mathrm{L}(\mu \mathrm{H})$ & $\mathrm{C}(\mu \mathrm{F})$ & $\mathrm{e}_{1}(\%)$ & $\mathrm{e}_{2}(\%)$ \\
\hline 10 & 700 & 9.8 & 40 & 100 & 6.25 & 0.54 \\
\hline 1.2 & 50 & 2.7 & 1.2 & 25 & 6.25 & 1.16 \\
\hline 2 & 25 & 1.2 & 1.1 & 25 & 0 & 1.2 \\
\hline 2 & 50 & 2.7 & 2.2 & 25 & 0 & 1.8 \\
\hline 0.25 & 100 & 14.3 & 1.3 & 10 & 0 & 0.075 \\
\hline 1 & 200 & 11.4 & 4.1 & 25 & 0 & 0.15 \\
\hline 10 & 350 & 19 & 76.8 & 25 & 0 & 0.2 \\
\hline 1 & 5 & 0.43 & 0.28 & 10 & 0 & 2 \\
\hline 4 & 10 & 0.3 & 0.5 & 25 & $\mathbf{3 7 . 5}$ & 0.1 \\
\hline 8 & 20 & 0.6 & 2.4 & 25 & $\mathbf{2 9 . 7}$ & 6 \\
\hline
\end{tabular}

Table 4. The parameters of Heilder equation

\begin{tabular}{|l|l|l|l|l|l|}
\hline $\mathrm{t}_{\mathrm{ds}}$ & $\mathrm{t}_{\mathrm{s}}$ & $\mathrm{\tau}_{\mathbf{1}}$ & $\mathrm{\tau}_{\mathbf{2}}$ & $\mathrm{e}_{1}(\%)$ & $\mathrm{e}_{2}(\%)$ \\
\hline & & & & & \\
4 & 10 & $7.52 \mathrm{E}-6$ & $8.6562 \mathrm{E}-6$ & $\mathbf{2 1 . 8 7 5}$ & $\mathbf{1 1}$ \\
\hline & & & & & \\
8 & 20 & $1.504 \mathrm{E}-5$ & $1.7312 \mathrm{E}-5$ & $\mathbf{2 1 . 8 7 5}$ & $\mathbf{1 0}$ \\
\hline
\end{tabular}




\subsection{Parameters correction}

To obtain a better result, a correction needs performing to compensate for assuming $x(t)=\frac{\left(\frac{t}{\tau_{1}}\right)^{10}}{\left(\frac{t}{\tau_{1}}\right)^{10}+1}=1 \quad$ and $y(t)=e^{\frac{-t}{\tau_{2}}}$. The correction of increasing current time coefficient and decreasing current time coefficient must be done to make functions $\mathrm{x}(\mathrm{t})$ and $\mathrm{y}(\mathrm{t})$ decrease because these functions are less than one before the approximate method is performed.

In the case of the functions, $x(t)$ decreases when $\left(\frac{t}{\tau_{1}}\right)^{10}$ decreases, which means that $\tau_{1}$ increases.

On the other hand, function $y(t)=e^{\frac{-t}{\tau_{2}}}$ decreases if $\tau_{2}$ decreases.

Correcting flowchart is presented in Figure 4, and Table 5 presents the parameters after correcting algorithm has been performed. Through this table, all wave shapes meet the standards.

Table 5. The corrected parameters of Heilder equation

\begin{tabular}{|c|c|c|c|c|c|}
\hline $\begin{array}{r}\mathrm{tds} \\
(\mu \mathrm{s})\end{array}$ & $\begin{array}{l}\mathrm{ts} \\
(\mu \mathrm{s})\end{array}$ & $\boldsymbol{\tau}_{\mathbf{1}}$ & $\boldsymbol{\tau}_{\mathbf{z}}$ & $\mathrm{e}_{1}(\%)$ & $\mathrm{e}_{2}(\%)$ \\
\hline 4 & 10 & $1.0446 \mathrm{E}-6$ & $5.885 \mathrm{E}-6$ & 0 & 3 \\
\hline 8 & 20 & $1.9898 \mathrm{E}-5$ & $1.239 \mathrm{E}-05$ & 1.5 & 2.5 \\
\hline
\end{tabular}

Estimate initial parameter(equation 11-12)

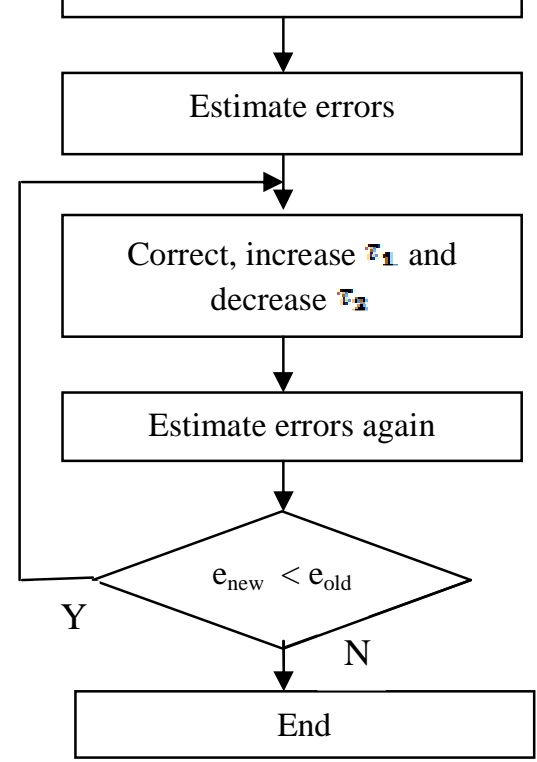

Figure 4. Correction flowchart

\section{CONCLUSION}

This work has estimated parameters $\mathrm{R}, \mathrm{L}$ and $\mathrm{C}$ for lighting current generator available to generate various wave shapes 10/700, 1.2/50, 2/25, 2/50, $0.25 / 100,1 / 200,10 / 350$, and $1 / 5 \mu$ s which meet the standards.

Parameters R, L and C of lighting current generator $8 / 20 \mu$ s have reduced errors of the wave shape in correlation with a proposed model from $39.06 \%$ to $29.7 \%$.

Math models for lighting current generator $8 / 20 \mu \mathrm{s}$ and $4 / 10 \mu \mathrm{s}$ have the errors lower than proposed researches from $6 \%$ to $3 \%$. 


\title{
CẤC MÔ HÌNH MÁY PHÁT XUNG SÉT CẢI TIẾN
}

\author{
Quyền Huy Ánh ${ }^{(1)}$, Nguyễn Mạnh Hùng ${ }^{(1)}$, Tạ Văn Minh ${ }^{(2)}$ \\ (1) ĐH Sư Phạm Kỹ Thuật TPHCM \\ (2) Trường cao đẳng nghề Lilama
}

TÓM TĂT: Nhũng nghiên cúu về máy phát xung dòng sét trước đây sủ dụng các cấu hình mạch riêng biệt để tạo ra các dạng xung dòng sét khác nhau, điều này gây khó khăn cho việc nghiên cứu chế tạo các máy phát xung sét với giá thành hợp lý. Bên cạnh đó, một số mô hình toán học mô phỏng dòng xung sét còn chua đạt được độ sai số theo tiêu chuẩn. Bài báo này trình bày phưong án thiết kế máy phát xung sét chỉ dùng một cấu hình mạch và mô hình toán học máy phát xung sét xây dụng trong môi trường Matlab có độ chính xác cao.

\section{REFERENCES}

[1] C.

$$
\text { Politano, SGS-THOMSON }
$$

Microelectronics, Protection standards applicable to terminalsItalia (1995).
[2] Trần Tùng Giang, Combination lighting generator and non-linear resistor model, Master thesis, Hồ Chí Minh University of Technical Education (2007). 